Kornberg, H. L. \& Sadler, J. R. (1960). Nature, Lond., 185, 153.

Large, P. J. \& Quayle, J. R. (1963). Biochem. J. 87, 386.

Leadbetter, E. \& Foster, J. W. (1958). Arch. Mikrobiol. 30, 91.

MacFadyen, D. A. (1945). J. biol. Chem. 158, 107.

Peel, D. \& Quayle, J. R. (1961). Biochem. J. 81, 465.

Quayle, J. R. (1961). Annu. Rev. Microbiol. 15, 119.

Rhodes, M. E. (1958). J. gen. Microbiol. 18, 639.
Takamiya, A. (1942). Acta phytochim. 13, 1.

Takamiya, A. (1943). Acta phytochim. 13, 193.

Takamiya, A. (1953). J. Biochem., Tokyo, 40, 415.

Treadwell, F. P. \& Hall, W. T. (1935). Analytical Chemistry, vol. 2, p. 369. New York: John Wiley and Sons, Inc.

Umbreit, W. W., Burris, R. M. \& Stauffer, J. F. (1957). Manometric Techniques. Minneapolis: Burgess Publishing Co.

Zatman, L. J. (1946). Biochem. J. 40, lxvii.

Biochem. J. (1964), 92, 614

\title{
The Microbial Oxidation of Methanol
}

\section{THE METHANOL-OXIDIZING ENZYME OF PSEUDOMONAS SP. M 27}

\author{
BY C. ANTHONY AND L. J. ZATMAN \\ Department of Microbiology, University of Reading
}

(Received 21 November 1963)

The preceding paper (Anthony \& Zatman, 1964) described the isolation and properties of Pseudomonas sp. M 27, an organism capable of growth on methanol, methylamine or formate as sole source of carbon and energy. The pathway of methanol assimilation in a similar organism, Pseudomonas AM 1 (Peel \& Quayle, 1961), has been investigated and data on several of the enzymes involved have been published (Large, Peel \& Quayle, 1962 ; Large \& Quayle, 1963). However, apart from catalase, no enzyme which catalyses the first essential oxidative step in methanol metabolism has been described; Anthony \& Zatman (1964) showed that catalase was not responsible for methanol oxidation in Pseudomonas sp. M27. All known alcohol dehydrogenases require NAD or NADP as coenzyme and none shows appreciable activity with methanol as substrate (Negelein \& Wulff, 1937; Racker, 1950; Barron \& Levine, 1952; Stafford \& Vennesland, 1953; DeMoss, 1954; Bonnichsen \& Brink, 1955; Atkinson \& Serat, 1960; Azoulay \& Heydeman, 1963). The present paper describes an enzyme system in Pseudomonas sp. M27 which catalyses methanol oxidation and which is independent of nicotinamide nucleotide coenzymes. A preliminary report of part of this work has been presented to The Society for General Microbiology (Anthony \& Zatman, 1963).

\section{MATERIALS AND METHODS}

Cytochrome $c$ and $N$-methylphenazonium methosulphate (phenazine methosulphate) were obtained from L. Light and Co. Ltd. The latter was stored at $2^{\circ}$ in the solid state and $1 \%(\mathrm{w} / \mathrm{v})$ solutions were stored frozen $\left(-22^{\circ}\right)$ in the dark. When thawed out for use solutions were still kept in the dark as far as possible. 2,6-Dichlorophenolindophenol was obtained from British Drug Houses Ltd. It was dissolved in water, left overnight and any insoluble material filtered off. It was standardized colorimetrically at $600 \mathrm{~m} \mu$; the molar extinction coefficient at $600 \mathrm{~m} \mu$ was taken to be $1.91 \times 10^{7} \mathrm{~cm}^{2} \mathrm{~mole}^{-1}$ (Basford \& Huennekens, 1955). NAD and NADP were obtained from Boehringer und Soehne, Mannheim, Germany. NAD nucleosidase of Neurospora crassa (500 units/ml.) was prepared according to the method of Kaplan (1955) and crystalline alcohol dehydrogenase of baker's yeast according to the method of Racker (1955). Buffers were prepared according to the data of Dawson, Elliott, Elliott \& Jones (1959).

Spectrophotometry. All spectrophotometric measurements were made with a Unicam SP. 500 spectrophotometer and cuvettes of $10 \mathrm{~mm}$. light-path.

Preparation of sonic extracts. Methanol-grown organisms were grown and harvested as described by Anthony \& Zatman (1964), and a suspension of $1.5 \mathrm{~g}$. wet wt. of organisms $/ 10 \mathrm{ml}$. of $0.05 \mathrm{M}$-phosphate buffer, pH $7 \cdot 0$, was prepared. This was exposed for 10-15 min. to ultrasonic oscillation at $20 \mathrm{kcyc}$./sec. in a $60 \mathrm{w}$ MSE-Mullard ultrasonic disintegrator with pure titanium probes (diameter $19 \mathrm{~mm}$.), the vessel containing the suspension being immersed in an ice bath. The suspension was treated in $10 \mathrm{ml}$. quantities in a small glass vessel whose diameter was hardly more than that of the probe, which was dipped just below the surface of the suspension. This treatment was sufficient to break most of the organisms, as judged by phase-contrast microscopy. After treatment the suspension was centrifuged at $35000 \mathrm{~g}$ for $1 \mathrm{hr}$. at $0^{\circ}$ and the pink almost clear supernatant liquid collected; this is referred to as the crude sonic extract.

Protein estimation. Two methods were used: the method of Lowry, Rosebrough, Farr \& Randall (1951) and the spectrophotometric method of Warburg \& Christian (1941). The procedures were those of DeMoss \& Bard (1957). Standard curves were prepared from crystallized bovine plasma albumin obtained from Armour Pharmaceutical Co. Ltd. 
Purification of the enzyme. The first step in purification consisted in removal of nucleic acids from crude sonic extracts by precipitation with protamine sulphate. The crude sonic extract was acidified to $\mathrm{pH} 6 \cdot 0$ with $\mathrm{M}$-acetic acid and a saturated solution of protamine sulphate (at $\mathrm{pH}$ 5.5) slowly added with stirring at room temperature. When a considerable precipitate had formed it was centrifuged off (35 $000 \mathrm{~g}$ for $10 \mathrm{~min}$.) and more protamine sulphate added to the supernatant liquid. This was repeated until no precipitate formed on adding more protamine sulphate. Much of the red particulate material of the crude sonic extract came down with the protamine sulphate precipitates; the final supernatant fluid was light brown in colour.

Ammonium sulphate fractionation was done at room temperature, solid $\left(\mathrm{NH}_{4}\right)_{2} \mathrm{SO}_{4}$ being added slowly with stirring to the supernatant liquid from the protamine sulphate treatment. The quantities of $\left(\mathrm{NH}_{4}\right)_{2} \mathrm{SO}_{4}$ to be added were determined from the nomogram of Dixon (1953). The precipitates were dissolved in a suitable volume of $0.05 \mathrm{M}$ phosphate buffer, $\mathrm{pH} 6.0$, and assayed for protein and enzyme activity.

\section{Enzyme assays}

The enzyme was assayed either spectrophotometrically by measuring the rate of reduction of 2,6-dichlorophenolindophenol, or manometrically by measuring the rate of oxygen uptake; both assay systems required PMS* as mediator.

Standard spectrophotometric assay. The cuvettes contained the following, in a total volume of $3 \mathrm{ml}$.: $0.3 \mathrm{~m}$-mole of tris$\mathrm{HCl}, \mathrm{pH} 9.0 ; 16 \mu$ moles of methanol; $0.33 \mu$ mole of PMS; $0 \cdot 13 \mu$ mole of 2,6 -dichlorophenol-indophenol; $3 \mu$ moles of $\mathrm{KCN} ; 45 \mu$ moles of $\mathrm{NH}_{4} \mathrm{Cl}$. The reference cuvette contained de-ionized water. Enzyme solution was blown in from a pipette and the rate of reduction taken as twice the change in extinction at $600 \mathrm{~m} \mu\left(E_{600}\right)$ occurring between 15 and 45 sec. after addition of enzyme. The amount of enzyme was limited so that the rate of change of $E_{600}$ was less than $0 \cdot 3 / \mathrm{min}$.

Enzyme units (spectrophotometric assay). One unit of enzyme activity as measured by the spectrophotometric assay is defined as the amount of enzyme sufficient to produce a change in $E_{600}$ of $0.01 / \mathrm{min}$. between 15 and $45 \mathrm{sec}$. after addition of the enzyme. Although endogenous reduction of dye was often considerable (see below) it was ignored for the purpose of this calculation. Assuming that the molar extinction coefficient of 2,6-dichlorophenol-indophenol at $600 \mathrm{~m} \mu$ is $1.91 \times 10^{7} \mathrm{~cm}^{2}$ mole $^{-1}$ (Basford \& Huennekens, 1955), 570 of these units are equivalent to one standard unit as defined in the Report of the Commission on Enzymes of the International Union of Biochemistry (1961).

Manometric assay. The reaction mixture for the manometric assay of enzyme with oxygen as final hydrogen acceptor was identical with the mixture for the spectrophotometric assay except that 2,6-dichlorophenol-indophenol and KCN were omitted and the amount of PMS was increased to $0.66 \mu$ mole. The rate of uptake of $\mathrm{O}_{2}$ was measured at $30^{\circ}$ between 2 and $7 \mathrm{~min}$. after tipping the enzyme into the reaction mixture from the side arm of the Warburg vessel.

Alternative primary hydrogen acceptors. Several hydrogen acceptors alternative to PMS were tested. Sufficient enzyme

* Abbreviation: PMS, $N$-methylphenazonium methosulphate (phenazine methosulphate). [crude sonic extract or $\left(\mathrm{NH}_{4}\right)_{2} \mathrm{SO}_{4}$ fraction] was used to give a very rapid reduction of 2,6-dichlorophenolindophenol in the standard spectrophotometric assay at $\mathrm{pH} 9 \cdot 0$. Each acceptor was tested at $\mathrm{pH} 7.0$ and pH 9.0. Oxygen uptake was measured in Warburg manometers at $30^{\circ}$, and reduction of methylene blue and 2,6-dichlorophenol-indophenol in evacuated Thunberg tubes. The spectrophotometer was used for measurement of nicotinamide nucleotide reduction (at $340 \mathrm{~m} \mu$ ), of cytochrome $c$ reduction (at $550 \mathrm{~m} \mu$ ) and of ferricyanide reduction (at $420 \mathrm{~m} \mu$ ) in the presence and absence of $1 \mathrm{~mm}-\mathrm{KCN}$. Methanol (100 $\mu$ moles) and $\mathrm{NH}_{4} \mathrm{Cl}(45 \mu$ moles $)$ were included in the $3 \mathrm{ml}$. reaction mixtures.

\section{Experiments involving nicotinamide nucleotide coenzymes}

Reduction of NAD or NADP. Crude sonic extracts and $\left(\mathrm{NH}_{4}\right)_{2} \mathrm{SO}_{4}$ fractions $(0 \cdot 2 \mathrm{mg}$. of protein/assay) were tested for ability to reduce NAD or NADP. The measurements were carried out spectrophotometrically by determining the increase in $E$ at $340 \mathrm{~m} \mu$. Methanol (16 $\mu$ moles) as substrate and $0.2 \mathrm{mg}$. of NAD or NADP were incubated in each of the assays, which were made in either tris-HCl, $\mathrm{pH} 9 \cdot 0$, or phosphate buffer, $\mathrm{pH} 7.0(0.05 \mathrm{~m}$ in each case $)$ in the presence or absence of ammonium salt (10 mM).

Effect of NAD nucleosidase. The methanol-oxidizing enzyme [ $\left(\mathrm{NH}_{4}\right)_{2} \mathrm{SO}_{4}$ fraction, $0.2 \mathrm{mg}$. of protein] was incubated for $8 \mathrm{~min}$. at $37^{\circ}$ in $0 \cdot 1 \mathrm{M}$-phosphate buffer, $\mathrm{pH} 7 \cdot 0$, with 10 units of NAD nucleosidase in a total volume $0.6 \mathrm{ml}$. The whole reaction mixture was then added to the standard spectrophotometric assay system and the rate recorded. The activity of the nucleosidase was confirmed by measuring its effect on NAD itself. NAD ( $0.2 \mathrm{mg}$.) was incubated in the nucleosidase reaction mixture as described above [in place of $\left(\mathrm{NH}_{4}\right)_{2} \mathrm{SO}_{4}$ enzyme fraction]. After incubation the rate of increase of $E_{340} / \mathrm{min}$. was measured on addition of the incubation mixture to a system containing alcohol dehydrogenase, $0 \cdot 1 \mathrm{M}$-tris- $\mathrm{HCl}, \mathrm{pH} 9 \cdot 0$, and $0.5 \mathrm{~m}$-ethanol. A control system without nucleosidase was also incubated and tested in a similar manner. It was found that this treatment completely destroyed the NAD.

\section{Activation of the methanol-oxidizing enzyme}

Dialysis. Enzyme preparations $\left[\left(\mathrm{NH}_{4}\right)_{2} \mathrm{SO}_{4}\right.$ fractions] were dialysed against 500 vol. of $0.05 \mathrm{M}$-phosphate buffer, $\mathrm{pH} 7 \cdot 0$, for $1 \mathrm{hr}$. at $0^{\circ}$.

Specificity of the activator. Several substances (all at $10 \mathrm{~mm}$ ) were tested for their ability to restore activity to dialysed enzyme preparations. A dialysed $\left(\mathrm{NH}_{4}\right)_{2} \mathrm{SO}_{4}$ fraction $(0.05 \mathrm{mg}$. of protein) was assayed in the standard spectrophotometric assay system (with omission of KCN and ammonium salt) containing one of the substances to be tested. When no dye reduction was observed $\mathrm{NH}_{4} \mathrm{Cl}(10 \mathrm{~mm}$ final concn.) was added and the rate of reaction measured.

Determination of the active species. The rate of reaction with dialysed enzyme $\left[65-80 \%\left(\mathrm{NH}_{4}\right)_{2} \mathrm{SO}_{4}\right.$ fraction, $0 \cdot 1 \mathrm{mg}$. of protein] was measured in the standard spectrophotometric assay at $\mathrm{pH} 9.0$ (omitting $\mathrm{KCN}$ ) with various concentrations of ammonium or methylammonium salt. Rates were determined in similar systems at $\mathrm{pH} 8.0$ in tris- $\mathrm{HCl}$ buffer $(0 \cdot 1 \mathrm{M})$.

Determination of $K_{m}$ for methanol. The rate of reaction with decreasing concentrations of methanol was measured 


\section{Table 1. Purification of the enzyme}

Activities were measured in the standard spectrophotometric assay system and protein was measured by the method of Lowry et al. (1951).

\section{Fraction}

Crude sonic extract

Protamine sulphate supernatant Ammonium sulphate fraction (65-80\% saturation)

Sp. activity
(units/mg. of
protein)
40
114
370

$\begin{array}{cc}\begin{array}{c}\text { Total } \\ \text { units }\end{array} & \begin{array}{c}\text { Yield } \\ (\%)\end{array} \\ 200000 & 100 \\ 170000 & 83 \\ 168000 & 83\end{array}$

Purification

(ml.)

100

150
2.9

$\mathbf{9 \cdot 3}$ in a system containing undialysed enzyme $[50-75 \%$ $\left(\mathrm{NH}_{4}\right)_{2} \mathrm{SO}_{4}$ fraction, $0.2 \mathrm{mg}$. of protein] and no added ammonium salt. This enzyme activity was dependent on the residual $\left(\mathrm{NH}_{4}\right)_{2} \mathrm{SO}_{4}$ in the $\left(\mathrm{NH}_{4}\right)_{2} \mathrm{SO}_{4}$ fraction which gave, however, only half the rate obtainable with added ammonium salt. This experiment was then repeated (with $0.15 \mathrm{mg}$. of protein) in the presence of sufficient ammonium salt to give maximum activity ( $7 \mathrm{~mm})$.

\section{Product of enzymic methanol oxidation}

The enzyme [( $\left.\mathrm{NH}_{4}\right)_{2} \mathrm{SO}_{4}$ fraction, $2 \mathrm{mg}$. of protein] was incubated in the manometric assay system (PMS/O $\mathrm{O}_{2}$; total volume, $6 \mathrm{ml}$.) in Warburg vessels at $30^{\circ}$. Samples $(2 \mathrm{ml}$.) were removed for determination of formaldehyde at zero time and after incubation for $30 \mathrm{~min}$. Each sample was introduced into a Markham (1942) still and washed in with about $3 \mathrm{ml}$. of water. The steam-distillate $(8-10 \mathrm{ml}$.) was made up to a total volume of $10 \mathrm{ml}$. and samples were analysed by the chromotropic acid reaction (MacFadyen, 1945); standard curves for this reagent were prepared as described by Anthony \& Zatman (1964). Control distillations of mixtures containing known amounts of formaldehyde gave a yield of formaldehyde in the distillate of only 25-35\%. This result was reproducible but the reason for the low yield is at present unknown.

\section{RESULTS}

Purification. The results obtained in a typical purification procedure are shown in Table 1. Most of the enzyme protein precipitated between 65 and $80 \%$ saturation with ammonium sulphate; this material is referred to in this paper as the ammonium sulphate fraction. A typical reaction curve (spectrophotometric assay) is given in Fig. 1. Further fractionation of this material with ammonium sulphate did not result in any significant increase in specific activity. No further purification was achieved by adsorption on calcium phosphate or alumina $\mathrm{C}_{\gamma}$ gels, gel filtration through Sephadex (G-100 and G-200) or column chromatography with CM- or DEAE-cellulose. Applying the techniques of Andrews \& Folley (1963) and Andrews (1964), the results obtained with Sephadex G-200 indicated that the molecular weight of the methanol-oxidizing enzyme is about 120000 . This has been confirmed by Dr P. Andrews (personal communication).

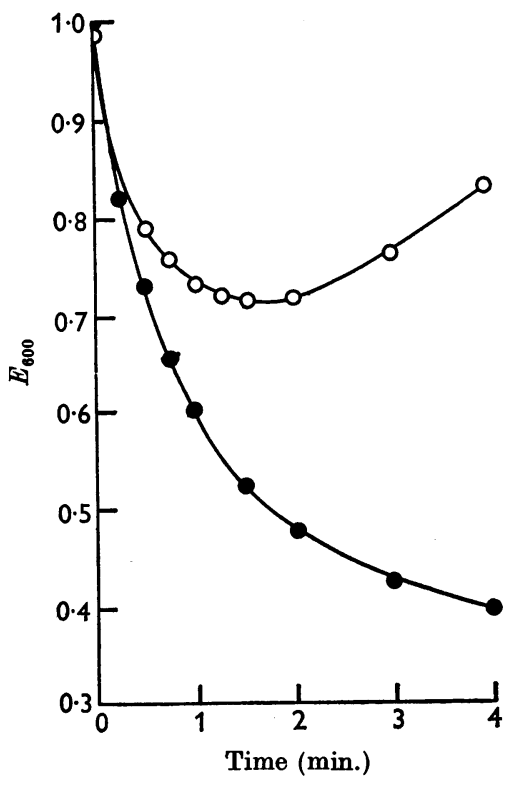

Fig. 1. Reduction of 2,6-dichlorophenol-indophenol catalysed by the methanol-oxidizing enzyme in the presence and absence of methanol (standard spectrophotometric assay). Reaction mixtures contained: $\mathbf{0 . 3}$ m-mole of tris-HCl, $\mathrm{pH}$ $9.0 ; 16 \mu$ moles of methanol; $0.33 \mu$ mole of PMS; $0.13 \mu$ mole of 2,6-dichlorophenol-indophenol; $45 \mu$ moles of $\mathrm{NH}_{4} \mathrm{Cl}$; $3 \mu$ moles of $\mathrm{KCN}$; dialysed $\left(\mathrm{NH}_{4}\right)_{2} \mathrm{SO}_{4}$ fraction $(0 \cdot 1 \mathrm{mg}$. of protein); water to $3 \mathrm{ml}$. $\mathrm{O}$, Without methanol; $\bigcirc$, with methanol.

\section{Variables in the spectrophotometric assay system}

pH value. The results in Fig. 2 show that the optimum pH value for enzyme activity was 9.0. Above this value, in the absence of enzyme, the phenazine methosulphate changed colour, turning red immediately at $\mathrm{pH} 10 \cdot 0$.

Substrate concentration. With an undialysed ammonium sulphate fraction $(0.1 \mathrm{mg}$. of protein), $40 \mu \mathrm{M}$-methanol was the minimum concentration of substrate which gave the maximum initial rate. $K_{m}$ for methanol is calculated below.

Ammonium sulphate concentration. The initial rate of reaction (with a dialysed ammonium 
sulphate fraction) reached a maximum and was proportional to the amount of enzyme present in the reaction mixture only with concentrations of ammonium sulphate greater than $7.5 \mathrm{~mm}$.

Phenazine methosulphate concentration. With an undialysed ammonium sulphate fraction $(0.3 \mathrm{mg}$. of protein), the initial rate of reduction of 2,6-dichlorophenol-indophenol reached a maximum only when the PMS concentration was $40 \mu \mathrm{M}$ or higher; $50 \%$ of this maximum rate was obtained with $20 \mu \mathrm{M}$ PMS.

2,6-Dichlorophenol-indophenol concentration. With a dialysed ammonium sulphate fraction $(0 \cdot 1 \mathrm{mg}$. of protein), the initial rate of reaction was directly proportional to the concentration of 2,6-dichlorophenol-indophenol; this probably explains the nonlinearity of the curve in Fig. 1. Although it would be desirable to use a concentration of 2,6-dichlorophenol-indophenol which is not rate-limiting, this was not possible directly because concentrations of 2,6-dichlorophenol-indophenol greater than $43 \mu \mathrm{M}$ gave an initial $E_{600}$ greater than 1.0, making accurate measurement impossible. However, when measurements of reaction rates were made over the first 45 sec., the change in concentration of 2,6dichlorophenol-indophenol during this period could be neglected and the initial rates were then directly proportional to the enzyme concentration.

Assay of enzyme in crude sonic extracts. It was found that $1 \mathrm{~mm}$-potassium cyanide increased the

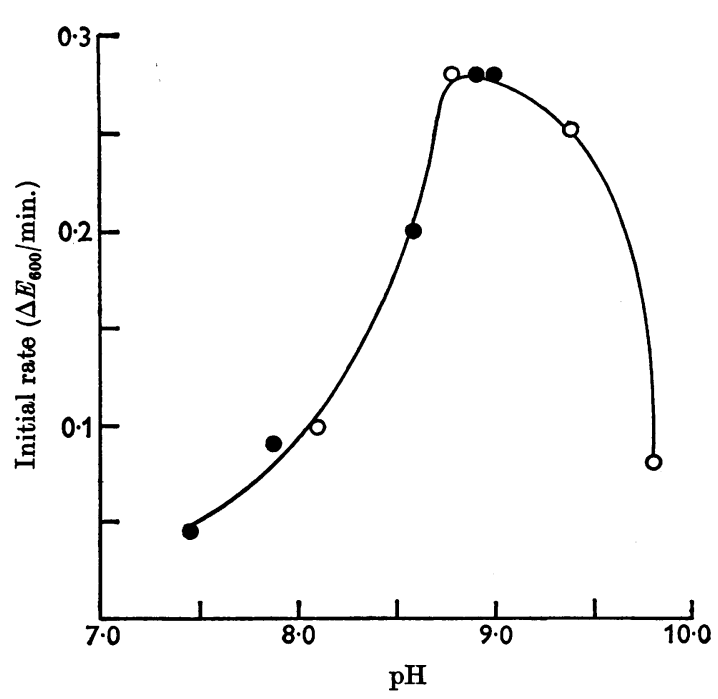

Fig. 2. Effect of $\mathrm{pH}$ on the enzymic oxidation of methanol (spectrophotometric assay). Reaction mixtures contained: $0.3 \mathrm{~m}$-mole of buffer; $16 \mu$ moles of methanol; $0.33 \mu$ mole of PMS; $0.13 \mu \mathrm{mole}$ of 2,6-dichlorophenol-indophenol; undialysed $\left(\mathrm{NH}_{4}\right)_{2} \mathrm{SO}_{4}$ fraction $(0 \cdot 4 \mathrm{mg}$. of protein); water to $3 \mathrm{ml}$. $O$, Tris-HCl buffer; $\mathrm{O}$, glycine-NaOH buffer. rate of reduction of 2,6-dichlorophenol-indophenol in the presence of crude sonic extracts by $25 \%$. There was no effect on the rate obtained with ammonium sulphate fractions. Presumably the cyanide inhibits the cytochrome system which catalyses the re-oxidation of reduced PMS by air. The rate of reduction of 2,6-dichlorophenol-indophenol by crude sonic extracts was inhibited $50 \%$ by $20 \mathrm{~mm}$ potassium cyanide.

Endogenous reduction of dye. A considerable reduction of 2,6-dichlorophenol-indophenol often occurred on adding enzyme to the reaction mixture in the absence of methanol (Fig. 1). This endogenous activity, which was dependent on the presence of PMS and ammonium salt, was found with all crude sonic extracts and with some ammonium sulphate fractions. Prolonged dialysis $\left(18 \mathrm{hr}\right.$. at $2^{\circ}$ ) of the enzyme preparations led to loss of endogenous activity and of activity with methanol (measured in the absence of ammonium salt); both activities were restored by including ammonium salt in the reaction mixture. These results indicate that the endogenous reduction of 2,6-dichlorophenol-indophenol was mediated by the methanol-oxidizing enzyme, but that the endogenous substrate was not free methanol.

Primary hydrogen acceptor. In the absence of PMS no reduction of NAD, NADP, cytochrome $c$ or ferricyanide was observed and no uptake of oxygen occurred. Although methylene blue and 2,6dichlorophenol-indophenol were eventually reduced in the absence of PMS, the highest rate obtained was much less than $1 \%$ of the rate obtained in the presence of PMS at $\mathbf{p H} \mathbf{9 \cdot 0}$.

Alternative final hydrogen acceptors. 2,6-Dichlorophenol-indophenol was replaced in the standard spectrophotometric assay system by $0.1 \mathrm{ml}$. of $1 \%$ cytochrome $c$ and its reduction measured at $550 \mathrm{~m} \mu$; the reference cuvette contained the same amount of cytochrome $c$ in water. The initial rate of cytochrome $c$ reduction was about one-tenth of that for reduction of 2,6-dichlorophenol-indophenol.

The spectrophotometric assay system without 2,6-dichlorophenol-indophenol and potassium cyanide was used to show that molecular oxygen would act as final hydrogen acceptor. In Warburg manometers the rate of oxygen uptake was linear so long as methanol was present. Although 0.33 $\mu$ mole of PMS gave maximum velocity in the spectrophotometric assay, the maximum rate of oxygen uptake was not obtained even with $1.32 \mu$ moles of PMS. The highest rate obtained with oxygen (with $1.32 \mu$ moles of PMS) was about half that obtained with 2,6-dichlorophenol-indophenol.

Dialysis of enzyme preparations led to complete loss of activity (in the absence of added ammonium salt) with 2,6-dichlorophenol-indophenol, cyto- 
chrome $c$ or oxygen as final hydrogen acceptor. The inclusion of ammonium salt in the reaction mixture completely restored the activity in all cases.

For some experiments the use of oxygen as final hydrogen acceptor is preferable because the enzyme reaction can then be followed for a longer period of time and also because reagents which spontaneously reduce 2,6-dichlorophenol-indophenol can be used.

Evidence against the participation of nicotinamide nucleotide coenzymes in enzymic methanol oxidation

The methanol-oxidizing enzyme (both crude sonic extract and ammonium sulphate fraction) was tested under various experimental conditions for ability to reduce NAD or NADP (see Materials and Methods section). In no case was the increase in $E_{340}$ in the presence of methanol greater in rate or extent than in its absence. The maximum rate obtained was an increase in $E_{340}$ of 0.02 in $5 \mathrm{~min}$.

Inclusion of NAD or NADP $(0.2 \mathrm{mg}$.) in the standard spectrophotometric assay system had no effect on the rate of reaction obtained with the purified enzyme. Likewise neither NAD nor NADP had any effect on the rates obtained in the same system at pH 7.0 (phosphate buffer).

Dialysis of purified enzyme preparations against 500 vol. of $0.05 \mathrm{M}$-phosphate buffer, pH 7.0, at $2^{\circ}$ for a period of $30 \mathrm{~min}$. or of $18 \mathrm{hr}$. led to complete loss of activity as measured in the standard spectrophotometric assay system containing no ammonium salt; addition of ammonium salt completely restored activity. Replacement of ammonium salt by NAD or NADP was ineffective for restoration of activity. Crude sonic extracts were usually active in the absence of added ammonium salt and although dialysis for $1 \mathrm{hr}$. had no effect, dialysis for $18 \mathrm{hr}$. led to complete loss of activity. Ammonium salt, but not NAD or NADP, restored this activity.

If preparations of methanol-oxidizing enzyme contain NAD or NADP (free or bound) which is essential for activity then treatment with NAD nucleosidase of Neurospora crassa (Kaplan, 1955; Astrachan, Colowick \& Kaplan, 1957) should lead to inactivation. It was found that incubation of enzyme (ammonium sulphate fraction, $0.2 \mathrm{mg}$. of protein), with an amount of NAD nucleosidase sufficient to inactivate $0.2 \mathrm{mg}$. of $\mathrm{NAD}$, had no effect on the methanol-oxidizing activity of ammonium sulphate fractions.

\section{Activation of the methanol-oxidizing enzyme}

Dialysis of enzyme preparations (ammonium sulphate fractions) against 500 vol. of $0.05 \mathrm{M}$ phosphate buffer, $\mathrm{pH} 7 \cdot 0$, for $1 \mathrm{hr}$. at $0^{\circ}$ resulted in complete loss of activity; this was completely restored by inclusion of ammonium salts in the reaction mixture.
Specificity of the activator. Several enzymes are known which are non-specifically activated by $\mathrm{NH}_{4}+$ ions. Potassium or $\mathrm{Rb}^{+}$ions will often replace $\mathrm{NH}_{4}+$ ions, and $\mathrm{Na}^{+}$or $\mathrm{Li}^{+}$ions are sometimes competitive inhibitors of this activation (Dixon \& Webb, 1964). No such replacement or antagonism was observed in the standard spectrophotometric assay system (omitting potassium cyanide and ammonium chloride) with the methanol-oxidizing enzyme (dialysed ammonium sulphate fraction) and the chlorides of lithium, sodium, potassium, rubidium, magnesium or calcium (all at $100 \mathrm{~mm}$ ). The activation of the enzyme was independent of the anion of the ammonium salt; the chloride, bromide, nitrate, sulphate, dihydrogen phosphate and bicarbonate were equally effective. Methylamine hydrochloride was the only substance tested which replaced ammonium salts as activator in this system (see Fig. 3); the following (all at $10 \mathrm{~mm}$ ) were inactive: dimethylamine hydrochloride, trimethylamine hydrochloride, tetramethylamine hydrobromide, ethylamine hydrochloride, diethylamine hydrochloride, tetraethylamine hydrochloride, cetyltrimethylamine hydrobromide, choline hydrochloride, aniline hydrochloride, glycine and serine.

Determination of the active species in ammonium chloride. To determine whether $\mathrm{NH}_{4}+$ ion or ammonia base $\left(\mathrm{NH}_{3}\right)$ is the activating species, the activity of an enzyme preparation was measured at two pH values in the presence of various concentrations of ammonium chloride and methylamine hydrochloride. At the vertical broken line (marked $X$ ) in Fig. 3 the concentration of added salt was the rate-limiting factor. At $\mathrm{X}$ with ammonium chloride there is a drop in rate to about one-tenth on decreasing the $\mathrm{pH}$ from $9 \cdot 0$ to $8 \cdot 0$. As the concentration of free base was also decreased with this decrease in pH it would appear that the free base rather than the quaternary ion is the active species. In support of this interpretation, at $\mathrm{X}$ the rate with methylamine hydrochloride at $\mathrm{pH} 9.0$ is one-tenth that with ammonium chloride at $\mathrm{pH} 9 \cdot 0$. The $\mathrm{p} K_{a}$ of the methylammonium ion (10.6) is about one unit higher than that of the $\mathrm{NH}_{4}+$ ion $(9 \cdot 3)$ and therefore in a system containing methylamine hydrochloride at pH 9.0 there is much less free base present than in a system containing ammonium salt.

The maximum rate with ammonium chloride at pH 8.0 was only about $35 \%$ of the maximum rate at pH 9.0, even with excess of ammonium chloride. This indicates that the increase in enzyme activity with increasing $\mathrm{pH}$ value was not due solely to the formation of necessary free base. The increasing concentration of necessary activator (free base) with increasing $\mathrm{pH}$ value may explain the logarithmic shape of the $\mathrm{pH}$-activity curve below $\mathrm{pH} \mathrm{9.0}$ (Fig. 2). 
Effect of ammonia on the Michaelis constant for methanol. In a further investigation of the role of ammonia, its effect on the Michaelis constant $\left(K_{m}\right)$ of the enzyme for its substrate was determined. The double reciprocal plot of the results (Lineweaver \& Burk, 1934) is shown in Fig. 4. With a rate-limiting concentration of ammonia $K_{m}$ for methanol is $7 \mu \mathrm{M}$, which is small, whereas with excess of ammonia, where the rate is a maximum, $K_{m}$ is increased by a factor of three.

Activity of the enzyme system in the absence of ammonia. Crude sonic extracts were active in the standard spectrophotometric assay system in the absence of ammonia but only after a lag period of 5-35 min.; they contained no ammonia and were still active after removal of nucleic acids with protamine sulphate. Ammonia was measured with Nessler's reagent; $1.0 \%$ of the amount required for enzyme activity could be detected by this method when added to the crude sonic extract. When the concentration of potassium cyanide was raised from $1 \mathrm{mM}$ to $10 \mathrm{mM}$ or when the reaction was carried out anaerobically in the absence of cyanide in Thunberg tubes, there was no lag period. In the presence of ammonia (with 1 mM-potassium

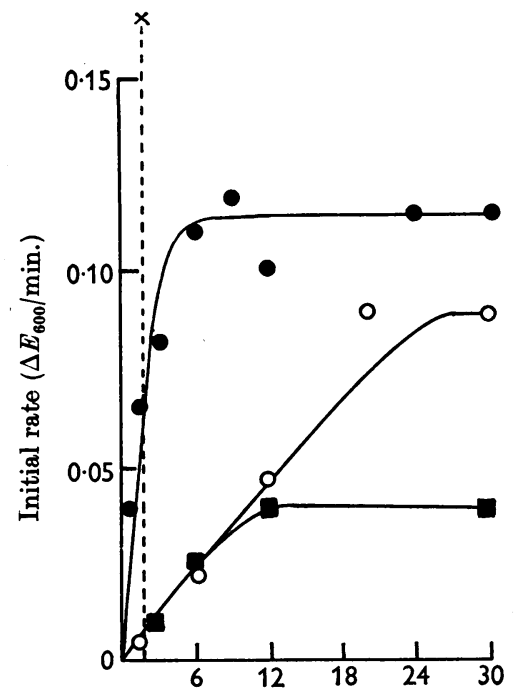

Concn. of ammonium or methylammonium chloride (mM)

Fig. 3. Rate of enzyme reaction as a function of salt concentration in the standard spectrophotometric assay (omitting KCN). Reaction mixtures contained: $0.3 \mathrm{~m}$ mole of tris-HCl; $16 \mu$ moles of methanol; $0.1 \mathrm{mg}$. of dialysed $\left(\mathrm{NH}_{4}\right)_{2} \mathrm{SO}_{4}$ fraction; $0.33 \mu$ mole of PMS; $0.13 \mu$ mole of 2,6-dichlorophenol-indophenol; water to $3 \mathrm{ml}$. , Ammonium chloride at $\mathrm{pH} \mathrm{9 \cdot 0;} \mathrm{O}$, methylammonium chloride at $\mathrm{pH} \mathrm{9.0;} \square, \mathrm{NH}_{4} \mathrm{Cl}$ at $\mathrm{pH} 8.0$. At $\mathrm{X}$ the concentration of added salt was the rate-limiting factor. cyanide) there was no lag period and the rate of reaction was 10-25 times as great as in its absence. Dialysis of crude sonic extract against $500 \mathrm{vol}$. of

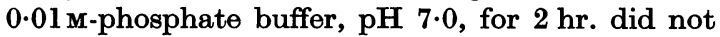
affect activity but all activity was lost after $18 \mathrm{hr}$. under similar conditions (in both cases the assays were carried out in the absence of ammonia). All activity was restored by inclusion of ammonia in the assay mixture, whether the dialysis was over the longer or the shorter period. These results suggest the presence in crude sonic extracts of either a slowly dialysable or a somewhat labile natural activator.

\section{Substrate specificity}

Exploratory experiments with the manometric assay system (PMS/oxygen) indicated that the enzyme (ammonium sulphate fraction) was not specific for methanol as substrate. Ethanol, propan1-ol, butan-1-ol, heptan-1-ol and nonan-1-ol were oxidized, but propan-2-ol, 2-methylpropan-1-ol, butan-2-ol and 2-methylpropan-2-ol were not.

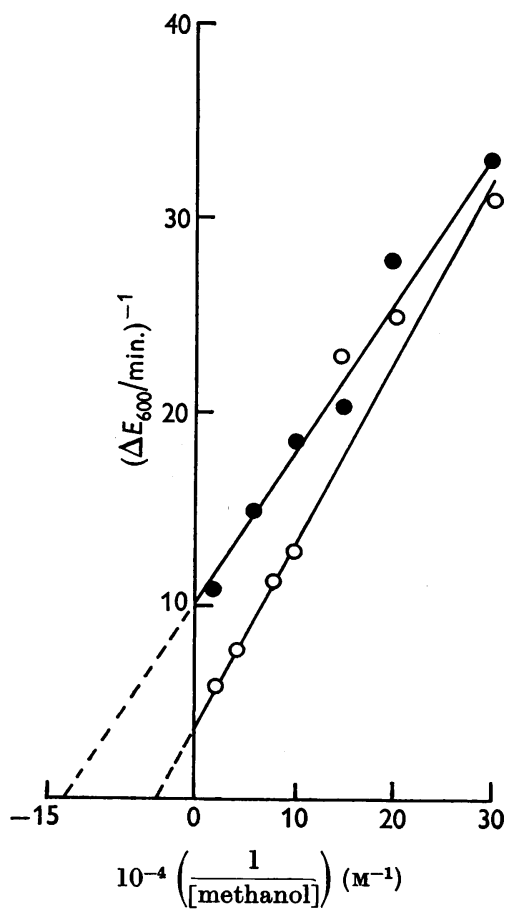

Fig. 4. Determination of $K_{m}$ for methanol. The standard spectrophotometric assay was used (omitting $\mathrm{KCN}$ ). Reaction mixtures contained: $0.3 \mathrm{~m}-$ mole of tris $-\mathrm{HCl}, \mathrm{pH}$ 9.0 ; $0.33 \mu$ mole of PMS; $0 \cdot 13 \mu$ mole of 2,6 -dichlorophenolindophenol; undialysed $\left(\mathrm{NH}_{4}\right)_{2} \mathrm{SO}_{4}$ fraction; water to $3 \mathrm{ml}$. , No added ammonia, $0.2 \mathrm{mg}$. of protein; $\bigcirc$, with $7 \mathrm{~mm}$ $\left(\mathrm{NH}_{4}\right)_{2} \mathrm{SO}_{4}, 0.15 \mathrm{mg}$. of protein. With rate-limiting $\mathrm{NH}_{4} \mathrm{Cl}$, $K_{m}=7 \mu \mathrm{M}$; with saturating $\mathrm{NH}_{4} \mathrm{Cl}, K_{m}=20 \mu \mathrm{M}$. 
Table 2. Estimation of formaldehyde in the steam-distillate after enzymic oxidation of methanol

Formaldehyde was estimated in the steam-distillate after the enzyme (ammonium sulphate fraction) had been incubated in the manometric assay system (PMS/oxygen) (see Materials and Methods section). The lower limit of the assay system is $70 \mu \mathrm{m}$-moles of formaldehyde.

\begin{tabular}{|c|c|c|c|}
\hline & Substrate in $6 \mathrm{ml}$. of reaction mixture & $\begin{array}{l}\text { Time of } \\
\text { incubation } \\
\text { (min.) }\end{array}$ & $\begin{array}{l}\text { Formaldehyde } \\
\text { ( } \mu \mathrm{m} \text {-moles } / \mathrm{ml} . \text { of } \\
\text { distillate })\end{array}$ \\
\hline No enzyme & $\begin{array}{l}\text { No substrate } \\
\text { Methanol }(40 \mu \text { moles }) \\
\text { Formaldehyde }(40 \mu \text { moles })\end{array}$ & $\begin{array}{l}\mathbf{0} \\
\mathbf{0} \\
\mathbf{0}\end{array}$ & $\begin{array}{r}<\mathbf{7 0} \\
<\mathbf{7 0} \\
\mathbf{3 7 0}\end{array}$ \\
\hline With enzyme & $\begin{array}{l}\text { No substrate } \\
\text { No substrate } \\
\text { Methanol ( } 40 \mu \text { moles) } \\
\text { Methanol (40 } \mu \text { moles) }\end{array}$ & $\begin{array}{r}0 \\
30 \\
0 \\
30\end{array}$ & $\begin{array}{r}<70 \\
<70 \\
<70 \\
440\end{array}$ \\
\hline
\end{tabular}

\section{Product of enzymic methanol oxidation}

Formaldehyde is a likely product of enzymic methanol oxidation. However, incubation mixtures cannot be assayed directly for formaldehyde by the chromotropic acid assay because PMS, an essential component of the incubation mixture, interferes. In some exploratory experiments the reaction product was separated from the PMS in the reaction mixture by steam-distillation in a Markham still (see Materials and Methods section). The results in Table 2 indicate that formaldehyde was formed during methanol oxidation by the enzyme in the manometric assay system (PMS/ oxygen). However, the term 'formaldehyde' as used here refers to formaldehyde as measured in the chromotropic acid reaction; this measurement involves heating the test sample at $100^{\circ}$ in $9 \mathrm{M}$ sulphuric acid, and such treatment could release free formaldehyde from a bound form. The presence of formaldehyde in the steam-distillate means that either free formaldehyde was present in the incubation mixture or that it was released either by the steam-distillation or in the chromotropic acid assay method. Whether the product is bound or free formaldehyde is at present unknown.

\section{DISCUSSION}

Bacillus extorquens, Protaminobacter ruber, Pseudomonas methanica, Pseudomonas sp. PRL-W 4 and Pseudomonas AM 1 are closely related organisms (Peel \& Quayle, 1961) and are closely related to Pseudomonas sp. M 27 (Anthony \& Zatman, 1964). The specificity of the methanol-oxidizing enzyme described in this paper with respect to phenazine methosulphate as hydrogen acceptor and ammonia as activator perhaps explains why no methanoloxidizing enzyme, apart from catalase, was demonstrated by Dworkin \& Foster (1956) or by Harrington \& Kallio (1960) in their strains of Pseudomonas methanica. The work of Kaneda \& Roxburgh (1959) with Pseudomonas sp. PRL-W4 indicated the presence of a NAD-linked methanol dehydrogenase. There is, however, no evidence for such an enzyme in Pseudomonas sp. M 27 (this paper), in Pseudo. monas methanica (Dworkin \& Foster, 1956; Harrington \& Kallio, 1960) or in Pseudomonas AM 1 (Dr P. Johnson and Dr J. R. Quayle, personal communication). Contrary to the interpretation of Harrington \& Kallio (1960) for Pseudomonas methanica, Anthony \& Zatman (1964) have presented evidence against the catalatic mechanism of methanol oxidation in Pseudomonas sp. M27. Dr Johnson and Dr Quayle (personal communication) have recently shown that enzymes similar to the one described above are also present in Pseudomonas AM 1, Pseudomonas methanica, Protaminobacter ruber and Bacillus extorquens and furthermore that all these enzymes require an ammonium salt for activity.

Activation by ammonia base $\left(\mathrm{NH}_{3}\right)$ is an unusual phenomenon and the activation by methylamine appears to be unique. Our evidence that crude sonic extracts contain a substance which is replaceable by ammonia suggests that ammonia might not be the physiological activator in the methanoloxidizing enzyme system. It is possible that the natural activator is another protein which can be replaced in vitro by ammonia, as with tryptophan synthase (Hatanaka, Horibata \& Crawford, 1962). No evidence has been obtained which implicates folic acid or its derivatives in methanol oxidation in this organism. Formaldehyde is thought to be assimilated as hydroxymethyltetrahydrofolate in Pseudomonas AMI (Large et al. 1962) and it is possible that methanol is oxidized to this bound form of formaldehyde in the complete enzyme system.

\section{SUMMARY}

1. Crude sonic extracts of methanol-grown Pseudomonas sp. M 27 contain an enzyme which catalyses the oxidation of methanol; this has been purified some tenfold. 
2. The enzyme is assayed spectrophotometrically by measuring the rate of reduction of 2,6-dichlorophenol-indophenol (or cytochrome c), or manometrically by measuring the rate of oxygen uptake. Both assay systems require phenazine methosulphate as primary hydrogen acceptor.

3. Dialysed enzyme preparations require ammonia or methylamine for activity.

4. The enzyme activity is independent of nicotinamide nucleotide coenzymes.

5. The optimum $\mathrm{pH}$ value of the enzyme is $9 \cdot 0$ and $K_{m}$ for methanol is $20 \mu \mathrm{M}$.

6. The enzyme is not specific for methanol as substrate; it will also catalyse the oxidation of other normal aliphatic alcohols.

We thank the University of Reading for the award of a Research Scholarship to C.A.

\section{REFERENCES}

Andrews, P. (1964). Biochem. J. 91, 222.

Andrews, P. \& Folley, S. J. (1963). Biochem. J. 87, 3 P.

Anthony, C. \& Zatman, L. J. (1963). J. gen. Microbiol. 31, xxi.

Anthony, C. \& Zatman, L. J. (1964). Biochem. J. 92, 609.

Astrachan, L., Colowick, C. P. \& Kaplan, N. O. (1957). Biochim. biophys. Acta, 24, 141.

Atkinson, D. E. \& Serat, W. F. (1960). Biochim. biophys. Acta, 39, 154.

Azoulay, E. \& Heydeman, M. T. (1963). Biochim. biophys. Acta, 73, 1.

Barron, E. S. G. \& Levine, S. (1952). Arch. Biochem. Biophys. 41, 175.

Basford, R. E. \& Huennekens, F. M. (1955). J. Amer. chem. Soc. 77, 3873.

Bonnichsen, R. K. \& Brink, N. G. (1955). In Methods in Enzymology, vol. 1, p. 495. Ed. by Colowick, S. P. \& Kaplan, N. O. New York: Academic Press Inc.
Dawson, R. M. C., Elliott, D. C., Elliott, W. H. \& Jones, K. M. (1959). Data for Biochemical Research. Oxford: Clarendon Press.

DeMoss, R. D. (1954). J. Bact. 68, 252.

DeMoss, R. D. \& Bard, R. C. (1957). In Manual of Microbiological Methods, p. 179. Society of American Bacteriologists, Committee on Bacteriological Technic. London: McGraw-Hill Book Co. Inc.

Dixon, M. (1953). Biochem. J. 54, 457.

Dixon, M. \& Webb, E. C. (1964). Enzymes, 2nd ed., p. 422. London: Longmans, Green and Co. Ltd.

Dworkin, M. \& Foster, J. W. (1956). J. Bact. 72, 646.

Harrington, A. A. \& Kallio, R. E. (1960). Canad. J. Microbiol. 6, 1.

Hatanaka, M., Horibata, K. \& Crawford, I. P. (1962). Arch. Biochem. Biophys. 97, 596.

Kaneda, T. \& Roxburgh, J. M. (1959). Canad. J. Microbiol. $5,197$.

Kaplan, N. O. (1955). In Methods in Enzymology, vol. 2, p. 644. Ed. by Colowick, S. P. \& Kaplan, N. O. New York: Academic Press Inc.

Large, P. J., Peel, D. \& Quayle, J. R. (1962). Biochem. J. $82,483$.

Large, P. J. \& Quayle, J. R. (1963). Biochem. J. 87, 386.

Lineweaver, H. \& Burk, D. (1934). J. Amer. chem. Soc. 56, 658.

Lowry, O. H., Rosebrough, N. J., Farr, A. L. \& Randall, R. J. (1951). J. biol. Chem. 193, 265.

MacFadyen, D. A. (1945). J. biol. Chem. 158, 107.

Markham, R. (1942). Biochem. J. 36, 790.

Negelein, E. \& Wulff, H. J. (1937). Biochem. Z. 293, 351.

Peel, D. \& Quayle, J. R. (1961). Biochem. J. 81, 465.

Racker, E. (1950). J. biol. Chem. 184, 313.

Racker, E. (1955). In Methods in Enzymology, vol. 1, p. 500. Ed. by Colowick, S. P. \& Kaplan, N. O. New York: Academic Press Inc.

Stafford, H. A. \& Vennesland, B. (1953). Arch. Biochem. Biophys. 44, 404.

Warburg, O. \& Christian. W. (1941). Biochem. Z. 310, 384.

Biochem. J. (1964), 92, 621

\title{
Metabolism of Polycyclic Compounds
}

\section{THE METABOLISM OF ANTHRACENE AND SOME RELATED COMPOUNDS IN RATS*}

\author{
By P. SIMS
}

Chester Beatty Research Institute, Institute of Cancer Research: Royal Cancer Hospital, London, S.W. 3

(Received 30 January 1964)

In the metabolism of benz $[a]$ anthracene by animals, a compound was detected that, after the hydrolyses of its sulphuric acid and glucuronic acid conjugates, yielded benz $[a]$ anthracene-7,12quinone (Boyland \& Sims, 1964b). The structure of

\footnotetext{
* Part 24: Boyland \& Sims (1964b).
}

this compound was not determined, but it seemed possible that it was either 7,12-dihydro-7,12dihydroxybenz $[a]$ anthracene or the related compound 7,12-dihydroxybenz $[a]$ anthracene. The metabolism of anthracene has, therefore, been reinvestigated and the formation of 9,10-dihydro9,10-dihydroxyanthracene, 9,10-dihydroxyanthra- 